\title{
Cyclopentadienyl chromium complexes with halide, methyl, isothiocyanate and isoselenocyanate ligands: Structures of $\left[\eta^{5}-\left(\mathrm{C}_{5} \mathrm{H}_{4}-\mathrm{COOCH}_{3}\right)\right] \mathrm{Cr}(\mathrm{NO})_{2}(\mathrm{Br})$ and $\left[\eta^{5}-\left(\mathrm{C}_{5} \mathrm{H}_{4}-\mathrm{COOCH}_{3}\right)\right] \mathrm{Cr}(\mathrm{NO})_{2}(\mathrm{~N}=\mathrm{C}=\mathrm{S})$
}

\author{
Yu-Pin Wang ${ }^{\mathrm{a}, *}$, Hsien-Li Leu ${ }^{\mathrm{a}}$, Yu Wang ${ }^{\mathrm{b}}$, Hsiu-Yao Cheng ${ }^{\mathrm{a}}$, Tso-Shen Lin ${ }^{\mathrm{a}}$ \\ a Department of Chemistry, Tunghai University, Taichung, Taiwan, ROC \\ b Department of Chemistry, National Taiwan University, Taipei, Taiwan, ROC
}

Received 25 January 2007; received in revised form 6 March 2007; accepted 6 March 2007

Available online 7 April 2007

\begin{abstract}
Bromination/nitrosylation of $\left[\eta^{5}\right.$-(carbomethoxy)cyclopentadienyl]dicarbonylnitrosylchromium $(\mathbf{8})$ (hereafter called carbomethoxycynichrodene) with hydrogen bromide/isoamyl nitrite gives bromo $\left[\eta^{5}\right.$-(carboxymethoxy)cyclopentadienyl]dinitrosylchromium (10) in $84 \%$. Compounds $\mathbf{1 5}$ in $74 \%$ and $\mathbf{1 6}$ in $90 \%$ were obtained from the corresponding cynichrodene derivatives via the same method. Compounds $\left[\eta^{5}\right.$-(carbomethoxy)cyclopentadienyl](isothiocyanato)dinitrosylchromium (13) and $\left[\eta^{5}\right.$-(carbomethoxy)cyclopentadienyl](isoselenocyanato)dinitrosylchromium (14) were prepared from $\left[\eta^{5}\right.$-(carbomethoxy)cyclopentadienyl]chlorodinitrosylchromium (9) with excess potassium thiocyanate and selenocyanate, respectively, after detaching the chloride by the action of silver nitrate. One of the nitrosyl groups in each compound is located at the site away from the exocyclic carbonyl carbon of the $\mathrm{Cp}(\mathrm{Cr})$ ring with twist angles of $168.5^{\circ}$ and $172.3^{\circ}$, respectively. The chemical shifts of $\mathrm{C}(2)-\mathrm{C}(5)$ carbon atoms of a series of substitutedcyclopentadienyldinitrosylchromium derivatives, $\left[\eta^{5}-\left(\mathrm{C}_{5} \mathrm{H}_{4}\right.\right.$-sub $\left.)\right] \mathrm{Cr}(\mathrm{NO})_{2} \mathrm{X}$, have been assigned using two-dimensional HetCOR NMR spectroscopy. The assigned chemical shifts were compared with the NMR data of their analogues of ferrocene, and the opposite correlation on the assignments was observed. The electron density distribution in the cyclopentadienyl ring is discussed on the basis of ${ }^{13} \mathrm{C}$ NMR data and those of $\mathbf{1 0}$ and $\mathbf{1 3}$ are compared with the calculations via density functional B3LYP correlation-exchange method.
\end{abstract}

(c) 2007 Elsevier B.V. All rights reserved.

Keywords: Organometallics; Cyclopentadienyl; Chromium; Cynichrodene; Nitrosyl; Isothiocyanate; Isoselenocyanate; Structure; ${ }^{13} \mathrm{C}$ NMR, B3LYP

\section{Introduction}

Since the advent of ferrocene in the early 1950 s, the syntheses and characterizations of metallocenes have been extensively studied, especially for the iron and tungsten compounds [1]. However, the number of chromium metallocenes being studied is relatively small. The number of isolated and well characterized $\mathrm{Cp}$-substituted bromo-

\footnotetext{
${ }^{*}$ Corresponding author. Fax: +886423590426.

E-mail address: ypwang@thu.edu.tw (Y.-P. Wang).
}

chromium, isothiocyanatochromium or isoselenocyanatochromium complexes is even more limited. In the case of $\mathrm{CpCr}(\mathrm{NO})_{2} \mathrm{Br}$, only one compound, $\mathrm{Cp}^{*} \mathrm{Cr}(\mathrm{NO})_{2} \mathrm{Br}$ [2], is reported in the literature. For $\mathrm{Cp}$ derivatives of compounds $\mathrm{CpCr}(\mathrm{NO})_{2}(\mathrm{~N}=\mathrm{C}=\mathrm{S})$ and $\mathrm{CpCr}(\mathrm{NO})_{2^{-}}$ $(\mathrm{N}=\mathrm{C}=\mathrm{Se})$, there are none.

The Cp-chromium compounds may have properties distinct from their iron analogues. Earlier [3], we reported the unequivocal assignments of $C(2,5)$ and $C(3,4)$ on the $C p$ ring of the $\mathrm{CpCr}(\mathrm{CO})_{2}(\mathrm{NO})$ (cynichrodene) derivatives bearing electron-withdrawing substituent in ${ }^{13} \mathrm{C} N M R$ spectra. The opposite correlation on the assignments 
between ferrocene and cynichrodene (1) was a surprising finding. In the case of ferrocene [4], the 3,4-positions are more sensitive to the electron-withdrawing substituent, while in the case of cynichrodene, the 2,5-positions are more sensitive to the electron-withdrawing substituent. The overall electron-withdrawing property of $\mathrm{CO}$ and NO ligands may exert the difference [3a]. This amazing finding prompted us to study the Cp-derivatives of 2-7, compounds with electron-withdrawing ligands, containing $(\mathrm{NO})_{2} \mathrm{Cl}, \quad(\mathrm{NO})_{2} \mathrm{Br}, \quad(\mathrm{NO})_{2}(\mathrm{I}), \quad(\mathrm{NO})_{2}\left(\mathrm{CH}_{3}\right), \quad(\mathrm{NO})_{2}(\mathrm{~N}-$ $\mathrm{C}=\mathrm{S})$, and $(\mathrm{NO})_{2}(\mathrm{~N}=\mathrm{C}=\mathrm{Se})$ moieties of chromium metallocenes [5].

Compounds 3, 6 and 7 were first reported in 1956, 1956 [6] and 1968 [7], respectively. The difficulties encountered for compounds 1-7 to undergo electrophilic aromatic substitution reactions such as Friedel-Crafts acylation have blocked the way to the synthesis of their respective $\mathrm{Cp}$ derivatives [8]. A novel method of replacing dicarbonyl with (NO)Cl ligand with hydrogen chloride/isoamylnitrite has been revealed by us to convert $\mathbf{1}$ to $\mathbf{2}$ [9]. The bromide analogues 10 and 15-16 were prepared with the use of hydrogen bromide/isoamylnitrite in place of hydrogen chloride/isomaylnitrite. The availability of 9 [9] makes the syntheses of carbomethoxy derivatives $\mathbf{1 3}$ and $\mathbf{1 4}$ accessible.

Herein, we report thorough spectral studies on 10, and 13-16, and the crystal structures of $\left[\eta^{5}-\left(\mathrm{C}_{5} \mathrm{H}_{4}\right.\right.$ $\left.\left.\mathrm{COOCH}_{3}\right]\right) \mathrm{Cr}(\mathrm{NO})_{2} \mathrm{Br} \quad(\mathbf{1 0})$ and $\left[\eta^{5}-\left(\mathrm{C}_{5} \mathrm{H}_{4}-\mathrm{COOCH}_{3}\right)-\right.$ $\mathrm{Cr}(\mathrm{NO})_{2}(\mathrm{~N}=\mathrm{C}=\mathrm{S})$ (13), the first $\mathrm{X}$-ray confirmed $\mathrm{Cr}$ isothiocyanate bonding structure $[10] .{ }^{13} \mathrm{C} \quad \mathrm{NMR}$ spectral comparisons between compounds 1-16 are also included.
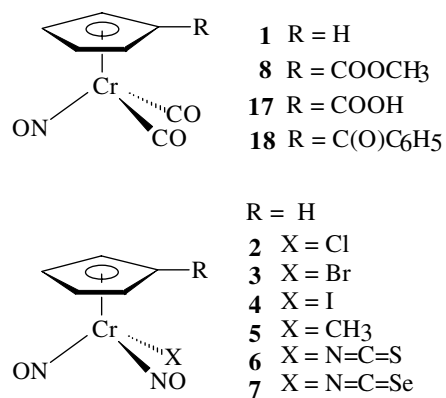

$\begin{array}{ll}\mathrm{R}=\mathrm{H} & \mathrm{R}=\mathrm{COOCH}_{3} \\ \mathbf{2} \mathrm{X}=\mathrm{Cl} & \mathbf{9} \mathrm{X}=\mathrm{Cl} \\ \mathbf{3} \mathrm{X}=\mathrm{Br} & \mathbf{1 0} \mathrm{X}=\mathrm{Br} \\ \mathbf{4} \mathrm{X}=\mathrm{I} & \mathbf{1 1} \mathrm{X}=\mathrm{I} \\ \mathbf{5} \mathrm{X}=\mathrm{CH}_{3} & \mathbf{1 2} \mathrm{X}=\mathrm{CH} 3 \\ \mathbf{6} \mathrm{X}=\mathrm{N}=\mathrm{C}=\mathrm{S} & \mathbf{1 3} \mathrm{X}=\mathrm{N}=\mathrm{C}=\mathrm{S} \\ \mathbf{7} \mathrm{X}=\mathrm{N}=\mathrm{C}=\mathrm{Se} & \mathbf{1 4} \mathrm{X}=\mathrm{N}=\mathrm{C}=\mathrm{Se}\end{array}$

\section{Results and discussion}

\subsection{Synthesis and characterization}

Bromination/nitrosylation of $\mathbf{8},\left(\eta^{5}\right.$-carboxycyclopentadienyl)dicarbonylnitrosylchromium (cynichrodenoic acid) (17), and ( $\eta^{5}$-benzoylcyclopentadienyl)dicarbonylnitrosylchromium (benzoylcynichrodene) (18) in isopropanol, a novel method of replacing dicarbonyl with $(\mathrm{NO}) \mathrm{Br}$ ligand [9], produced 10, 15 and 16 in $84 \%, 74 \%$, and $90 \%$ yield, respectively.

$$
\begin{aligned}
& \mathbf{8} \underset{\text { isopropanol }}{\mathrm{HBr} /\left(\mathrm{CH}_{3}\right)_{2} \mathrm{CHCH}_{2} \mathrm{CH}_{2} \mathrm{ONO}} \mathbf{1 0} \\
& \mathbf{1 7} \rightarrow \mathbf{1 5} \\
& \mathbf{1 8} \rightarrow \mathbf{1 6}
\end{aligned}
$$

Compound $\mathbf{1 3}$ in $50 \%$ and $\mathbf{1 4}$ in $49 \%$ were obtained by treating the halogen-free solution, obtained by the action of silver nitrate on 9 in $\mathrm{H}_{2} \mathrm{O} / \mathrm{CH}_{3} \mathrm{OH}(4 / 1)$, with excess potassium thiocyanate and selenocyanate, respectively.

$9 \stackrel{\mathrm{AgNO}_{3}}{\longrightarrow} \stackrel{\mathrm{KSCN}}{\longrightarrow} 13 \quad 9 \stackrel{\mathrm{AgNO}_{3} \mathrm{KSeCN}}{\longrightarrow} 14$

As is well known, both thiocyanate and selenocyanate are amphoteric nucleophiles; that is, they can S-bond or Nbond to a substrate. For a soft substrate,

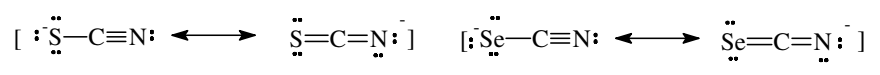

an S-bonded complex obtained, for a hard substrate, a $\mathrm{N}$ bonded complexes ended up. It is interesting to find which linkage, $\mathrm{Cr}-\mathrm{N}$ or $\mathrm{Cr}-\mathrm{S}(\mathrm{Se})$, is for compound $\mathbf{1 3}$ and $\mathbf{1 4}$. In 1968, Wojcicki et al. claimed the formation of 6 $\left(\mathrm{CpCr}(\mathrm{NO})_{2}(\mathrm{NCS})\right)$, a N-bonded isothiocyanate complex. They also found that with tungsten, only the S-bonded thiocyanate was isolated $\left(\mathrm{CpW}(\mathrm{CO})_{3}(\mathrm{SCN})\right)$; while with molybdenum both isomers, $\mathrm{CpMo}(\mathrm{CO})_{3}(\mathrm{NCS})$ and $\mathrm{CpMo}(\mathrm{CO})_{3}(\mathrm{SCN})$ were formed. The assignments they based were the positions of the $\mathrm{CN}$ stretching band, the S-bonded thiocynates(-SCN) absorbing at ca. $2120 \mathrm{~cm}^{-1}$, while the $\mathrm{N}$-bonded isothiocyanates(-NCS) at about $2100 \mathrm{~cm}^{-1}$. The difference is small $\left(20 \mathrm{~cm}^{-1}\right)$ and there are notable exceptions [10]. Herein, we reported the first X-ray confirmed Cr-isothiocyanato linkage compound, 13. The electron deficient substrate, $\mathrm{CpCr}(\mathrm{NO})_{2}{ }^{+}$, entails the thiocyanate to attack itself with the more basic site(nitrogen), so N-bonded isothiocyanato product was obtained. The same auguments hold for compound 14, since selenium nucleophiles are even more polarizable than sulfur analogues. On the basis of ${ }^{13} \mathrm{C}$ NMR, 14 was assigned to a nitrogen-bonded structure, $\left[\eta^{5}-\left(\mathrm{C}_{5} \mathrm{H}_{4}\right.\right.$ $\left.\left.\mathrm{COOCH}_{3}\right)\right] \mathrm{Cr}(\mathrm{NO})_{2}(\mathrm{~N}=\mathrm{C}=\mathrm{Se})$. The isoselenocyanato carbon of 14 resonates at $\delta 138.89 \mathrm{ppm}$, which is correlated well with $\delta 138.8$ from a series of organic compounds bearing a $-\mathrm{N}=\mathrm{C}=\mathrm{Se}$ substituent [11]. In the alternative linkage, selenocyanato carbon, may give a much lower value of $\delta$, a value of ca. $102 \mathrm{ppm}$ for organic compounds [12].

All compounds 9-14 exhibit two terminal nitrosyl stretching bands, the symmetric mode occurring at 1799$1844 \mathrm{~cm}^{-1}$ and the asymmetric mode at $1723-1734 \mathrm{~cm}^{-1}$. The absorption of organic carbonyl group is obscured by the asymmetric NO stretching band. The following order of increasing wavenumbers of symmetric NO stretching was observed: $\mathbf{1 2}\left(1780 \mathrm{~cm}^{-1}\right)<\mathbf{1 1} \quad\left(1821 \mathrm{~cm}^{-1}\right)<\mathbf{1 0}$ $\left(1826 \mathrm{~cm}^{-1}\right)<\mathbf{9}\left(1829 \mathrm{~cm}^{-1}\right)<\mathbf{1 3}\left(1839 \mathrm{~cm}^{-1}\right)$. This trend 
Table 1

${ }^{1} \mathrm{H}$ NMR data ${ }^{\mathrm{a}}$

\begin{tabular}{|c|c|c|c|c|}
\hline \multirow[t]{2}{*}{ Compound } & \multicolumn{2}{|l|}{$\mathrm{Cp}(\mathrm{Cr})$} & \multirow[t]{2}{*}{$-\mathrm{OCH}_{3}$} & \multirow[t]{2}{*}{$\mathrm{Cr}-\mathrm{CH}_{3}$} \\
\hline & $\mathrm{H}(2,5)$ & $\mathrm{H}(3,4)$ & & \\
\hline 1 & \multicolumn{2}{|c|}{$5.07(\mathrm{~s}, 5)$} & & \\
\hline 2 & \multicolumn{2}{|c|}{$5.73(\mathrm{~s}, 5)$} & & \\
\hline 3 & \multicolumn{2}{|c|}{$5.72(\mathrm{~s}, 5)$} & & \\
\hline 4 & \multicolumn{2}{|c|}{$5.78(\mathrm{~s}, 5)$} & & \\
\hline 5 & \multicolumn{2}{|c|}{$5.40(\mathrm{~s}, 5)$} & & 0.57 \\
\hline 6 & \multicolumn{2}{|c|}{$5.83(\mathrm{~s}, 5)$} & & \\
\hline 8 & $5.76(\mathrm{t}, 2)$ & $5.11(\mathrm{t}, 2)$ & $3.80(\mathrm{~s}, 3)$ & \\
\hline 9 & $6.25(\mathrm{t}, 2)$ & $5.78(\mathrm{t}, 2)$ & $3.89(\mathrm{~s}, 3)$ & \\
\hline 10 & $6.26(\mathrm{t}, 2)$ & $5.79(\mathrm{t}, 2)$ & $3.87(\mathrm{~s}, 3)$ & \\
\hline 11 & $6.29(\mathrm{t}, 2)$ & $5.82(\mathrm{t}, 2)$ & $3.85(\mathrm{~s}, 3)$ & \\
\hline 12 & $5.93(\mathrm{t}, 2)$ & $5.44(\mathrm{t}, 2)$ & $3.79(\mathrm{~s}, 3)$ & 0.63 \\
\hline 13 & $6.26(\mathrm{t}, 2)$ & $5.77(\mathrm{t}, 2)$ & $3.92(\mathrm{~s}, 3)$ & \\
\hline
\end{tabular}

${ }^{\text {a }}$ Data of 9, 11, 12 are obtained from Ref. [5].

is correlated well with the order of increasing tendency of electron-withdrawing property of a coordinated ligand on the chromium atom: $-\mathrm{CH}_{3}<\mathrm{I}<\mathrm{Br}<\mathrm{Cl}<-\mathrm{NCS}$. An electron-withdrawing lignad reduces the $\pi$ back-bonding from $\mathrm{Cr} \mathrm{d} \pi$-orbitals to the $\pi^{*}$ orbitals of NO

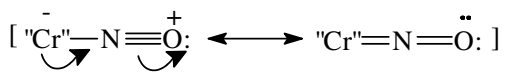

groups, and higher wavenumbers result. This trend reinforces the structure assignments for $\mathbf{1 3}$ and 14. In 1968, Wojcicki et al. [10] revealed that for a number of $\mathrm{C}_{5} \mathrm{H}_{5} \mathrm{M}(\mathrm{CO}) \times \mathrm{X}$ complexes the carbonyl stretching frequencies increased with the electron-withdrawing power of $\mathrm{X}$ in the order: $-\mathrm{I}<\mathrm{Br} \sim \mathrm{SCN}<\mathrm{Cl}<-\mathrm{NCS}$. The above criterion permits unambiguous differentiation between $\mathrm{Cr}-\mathrm{S}-$ $\mathrm{C} \equiv \mathrm{N}$ and $\mathrm{Cr}-\mathrm{N}=\mathrm{C}=\mathrm{S}$ linkages. Other functional groups of these compounds show their characteristic absorbances.

The ${ }^{1} \mathrm{H}$ NMR spectra of compounds 10, 13-16 are consistent with their assigned structures and are similar to other metallocenyl systems [3b-5] . All compounds 8-16 exhibit a pair of apparent triplet. The lowfield triplet can be assigned to $H(2,5)$ protons of the Cp. This assignment is made on the basis that the carbonyl group would exert stronger magnetic anisotropic effect to the ring protons closer to it. As expected, $H(2,5)$ would be deshielded to a greater extent than the protons on the more remote 3and 4-positions.

It is of interest to compare the ${ }^{1} \mathrm{H}$ NMR spectra of $\mathbf{8}-\mathbf{1 3}$ with their corresponding unsubstituted parent compounds 1-6 (Since the ${ }^{1} \mathrm{H}$-spectroscopic data of 7 had never been reported in the literature, the comparison of it with $\mathbf{1 4}$ was excluded.). The chemical shifts of protons on $\mathrm{Cp}(\mathrm{Cr})$ $(\mathrm{H}(3,4)$ and $\mathrm{H}(2,5))$ of $\mathbf{8}-\mathbf{1 3}$ occur at much lower fields than those of the corresponding protons of 1-6 (Table 1). This reflects the strong electron-withdrawing effect of the organic carbonyl group.

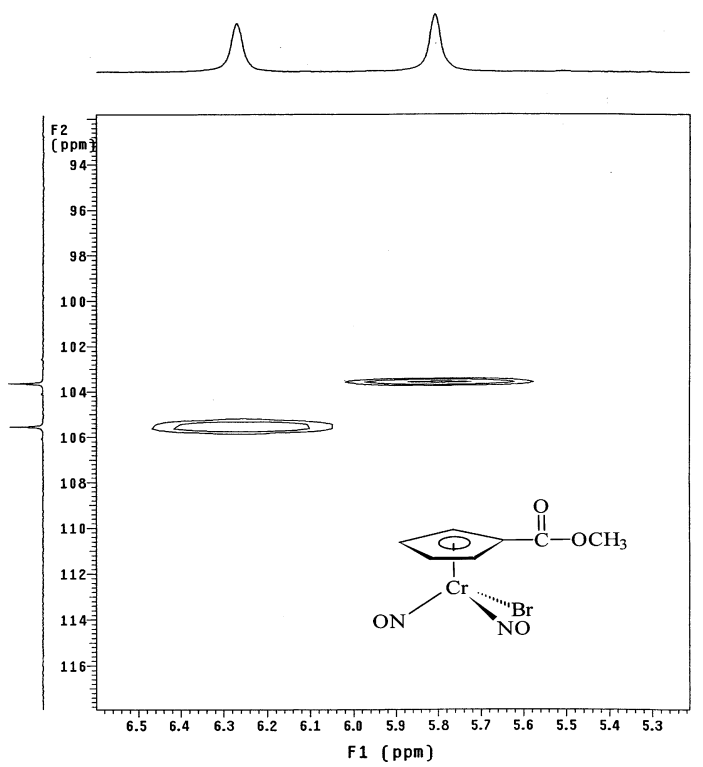

Fig. 1. 2D ${ }^{1} \mathrm{H}\left\{{ }^{13} \mathrm{C}\right\}$ HetCOR NMR spectrum of $\mathbf{1 0}$ in $\mathrm{CDCl}_{3}$.

Table 2

${ }^{13} \mathrm{C}\left\{{ }^{1} \mathrm{H}\right\}$ NMR data ${ }^{\mathrm{a}}$

\begin{tabular}{|c|c|c|c|c|c|c|c|}
\hline \multirow[t]{2}{*}{ Compound } & \multicolumn{3}{|l|}{$\mathrm{Cp}(\mathrm{Cr})$} & \multirow[t]{2}{*}{$\mathrm{Cr}-\mathrm{C} \equiv \mathrm{O}$} & \multirow[t]{2}{*}{$\mathrm{C}=\mathrm{O}$} & \multirow[t]{2}{*}{$-\mathrm{OCH}_{3}$} & \multirow[t]{2}{*}{$\mathrm{Cr}-\mathrm{CH}_{3}$} \\
\hline & $\mathrm{C}(1)$ & $C(2,5)$ & $\mathrm{C}(3,4)$ & & & & \\
\hline 1 & & $90.31(\mathrm{C}(1-5))$ & & 237.10 & & & \\
\hline 4 & & $101.32(\mathrm{C}(1-5))$ & & & & & \\
\hline 5 & & $99.24(\mathrm{C}(1-5))$ & & & & & -1.22 \\
\hline 8 & 92.94 & 94.12 & 91.74 & 234.67 & 165.07 & 52.16 & \\
\hline 9 & 103.14 & 106.05 & 104.14 & & 161.87 & 52.79 & \\
\hline 12 & 101.78 & 102.83 & 99.48 & & 163.65 & 52.08 & 0.85 \\
\hline 13 & 104.25 & 105.33 & 103.12 & & 161.41 & 53.19 & \\
\hline 14 & 102.64 & 102.40 & 100.91 & & 161.88 & 52.96 & \\
\hline 15 & 107.98 & 107.88 & 104.42 & & & & \\
\hline 16 & 107.49 & 106.64 & 103.35 & & 188.41 & & \\
\hline
\end{tabular}

${ }^{\text {a }}$ Chemical shifts are reported in ppm with respect to internal $\mathrm{Me}_{4} \mathrm{Si}$. 


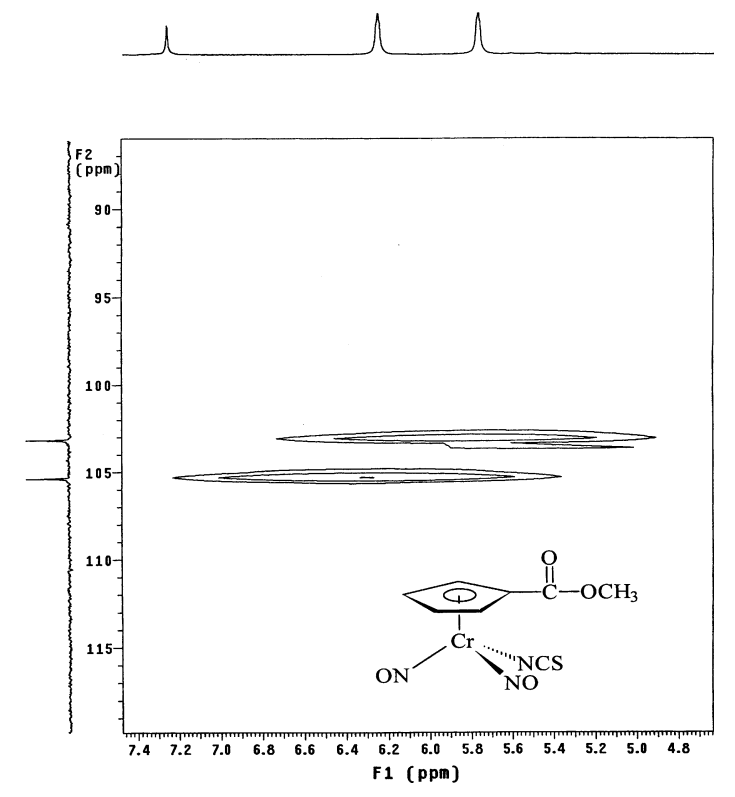

Fig. 2. $2 \mathrm{D}{ }^{1} \mathrm{H}\left\{{ }^{13} \mathrm{C}\right\}$ HetCOR NMR spectrum of $\mathbf{1 3}$ in $\mathrm{CDCl}_{3}$.

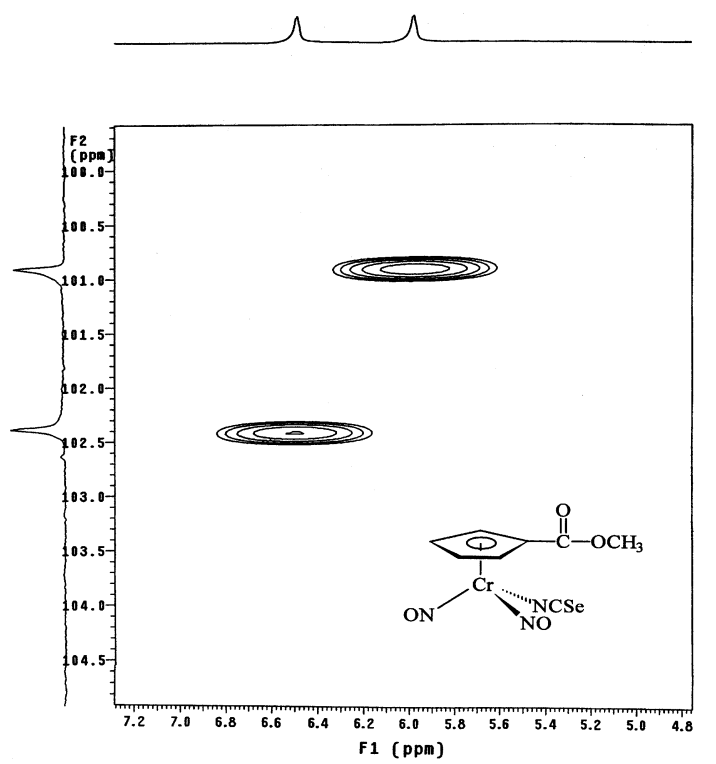

Fig. 3. $2 \mathrm{D}{ }^{1} \mathrm{H}\left\{{ }^{13} \mathrm{C}\right\}$ HetCOR NMR spectrum of $\mathbf{1 4}$ in $\mathrm{CDCl}_{3}$.

The assignments of ${ }^{13} \mathrm{C}$ NMR spectra of 10, 13-16 (Table 2) were based on standard ${ }^{13} \mathrm{C}$ NMR correlation [13], 2D HetCOR (Figs. 1-3), the DEPT technique and by comparison with other metallo-aromatic systems [14]. In the case of 10, two relatively less intense signals were observed at $\delta 161.99$ and 102.56 corresponding to the organic carbonyl carbon and $\mathrm{C}(1)$ of $\mathrm{Cp}(\mathrm{Cr})$, respectively. The methoxy carbon resonates at $\delta 52.82$. The line assignments for $\mathrm{C}(2-5)$ of $\mathrm{Cp}(\mathrm{Cr})$ were more difficult to make. Based on 2D-HetCOR, chemical shifts at $\delta 103.65$ and 105.56 were assigned to $C(3,4)$ and $C(2,5)$ of $C p(C r)$, respectively (Fig. 1). Similarly, in the case of 13, chemical
Table 3a

Selected net atomic charges for $\mathbf{1 0}$ using the $6-311++\mathrm{G}(\mathrm{d}, \mathrm{p})$ basis set

\begin{tabular}{lllll}
\hline $\mathrm{C}(1)$ & $\mathrm{C}(2)$ & $\mathrm{C}(3)$ & $\mathrm{C}(4)$ & $\mathrm{C}(5)$ \\
-0.18290 & 0.11927 & -0.22087 & -0.18500 & -0.17839 \\
\hline
\end{tabular}

Table $3 b$

Selected net atomic charges for $\mathbf{1 3}$ using the $6-311++\mathrm{G}(\mathrm{d}, \mathrm{p})$ basis set

\begin{tabular}{lllll}
\hline $\mathrm{C}(1)$ & $\mathrm{C}(2)$ & $\mathrm{C}(3)$ & $\mathrm{C}(4)$ & $\mathrm{C}(5)$ \\
-0.19908 & -0.15829 & -0.18701 & -0.19716 & 0.11584 \\
\hline
\end{tabular}

shifts of $\delta 103.12$ and 105.33 were assigned to $\mathrm{C}(3,4)$ and $\mathrm{C}(2,5)$ of $\mathrm{Cp}(\mathrm{Cr})$ (Fig. 2); and in the case of 14, chemical shifts of $\delta 100.91$ and 102.40 were assigned to $C(3,4)$ and $\mathrm{C}(2,5)$ of $\mathrm{Cp}(\mathrm{Cr})$, respectively (Fig. 3). It is of interest to compare the ${ }^{13} \mathrm{C}$ NMR spectra of $\mathbf{8}-\mathbf{1 4}$ with their unsubstituted parent compound 1-7. However, the lack data of 3, $\mathbf{6}$, and $\mathbf{7}$ from literature only the comparison of $\mathbf{8}, \mathbf{9}, \mathbf{1 1}$ and $\mathbf{1 2}$ with 1, 2, 4 and $\mathbf{5}$ were made. For the carbon atoms on $\mathrm{Cp}(\mathrm{Cr}(\mathrm{C}(3,4))$ and $\mathrm{C}(2,5))$, the chemical shifts occur at lower field than the chemical shifts of their parent compounds (Table 3). This reflects the strong electron-withdrawing effect of carbonyl substituent on the $\mathrm{Cp}$ ring.

One surprising finding in the study of ${ }^{13} \mathrm{C}$ spectra of 8 16 (Table 2) is that the highfield and lowfield chemical shifts are assigned to $C(3,4)$ and $C(2,5)$, respectively for electron-withdrawing carbonyl substituent on $\mathrm{Cp}$ ring which is opposite to the assignment of ferrocene derivatives $[14,9]$ in which the lowfield shifts and highfield shifts are assigned to $C(3,4)$ and $C(2,5)$. In ferrocenes, the 3,4-positions of the substituted cyclopentadienyl ring are more sensitive to electron-withdrawing substituents by resonance, while in cynichrodenes the 2,5-positions of the substituted cyclopentadienyl ring are more sensitive to electron-withdrawing substituents.
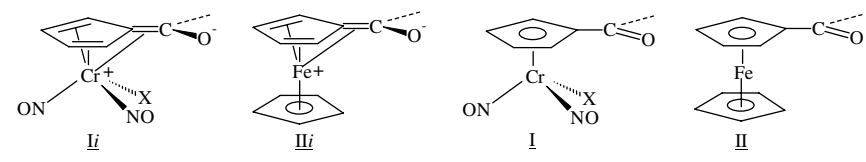

The smaller contribution of canonical form I $i$ than II $i i$ to each of the corresponding structures I and II may explain such behaviour. This is understandable in the destabilization of chromium cation because of the overall electron-withdrawing properties of two NO and X ligands. Therefore, in cyclopentadienyl chromium complexes, $\mathrm{CpCr}(\mathrm{NO})_{2} \mathrm{X}$, bearing a electron-withdrawing substituent, the inductive effect that deshields the nearby carbon $(\mathrm{C}(2,5))$ atoms to a greater extent than the more distant 3- and 4-positions may explain the observed data collected in Table 2 (C13 Table).

An important advantage of the ${ }^{13} \mathrm{C}$ NMR method over ${ }^{1} \mathrm{H}$ NMR spectroscopy is the relatively lower susceptibility of ${ }^{13} \mathrm{C}$ chemical shifts to the effects of magnetically aniso- 
tropic groups and ring current [15]. Therefore, ${ }^{13} \mathrm{C}$ NMR spectra provide a clearer picture of the electron density distribution within a molecule than do proton NMR spectra. Thus, to obtain the unequivocal assignments of $\mathrm{C}(2,5)$ and $\mathrm{C}(3,4)$ on the $\mathrm{Cp}$ ring, the use of $2 \mathrm{D}$ HetCOR NMR spectroscopy is highly recommended, especially for metals coordinated with ligands bearing strong electron-withdrawing property.

The unequivocal assignments of ${ }^{13} \mathrm{C}$ chemical shifts for 10 and 13 were correlated well with the ab initio calculations from the X-ray data of $\mathbf{1 0}$ and 13. The average charges of $C(2,5)$ and $C(3,4)$ are -0.149 and -0.203 for 10; and -0.137 and -0.192 for $\mathbf{1 3}$ (Tables $3 a$ and $3 b$ ).
The molecular structure of $\mathbf{1 0}$ and $\mathbf{1 3}$ are shown in Figs. 4 and 5, respectively. Selected bond distances and angles are given in Tables 4 and 5. The atomic coordinates of the non-hydrogen atoms are listed in Tables 6 and 7, respectively.

The coordination geometry about the $\mathrm{Cr}$ center in each case is approximately a distorted tetrahedron with two nitrosyl groups, the $\mathrm{Cp}$ group and $\mathrm{X}(\mathrm{X}=$ bromide for $\mathbf{1 0}$, and isothiocyanate for 13) as the four coordination sites. It is worth pointing out that for all the structures of $\mathbf{9}[5], \mathbf{1 0}, 11$ [5], and 13, one of the nitrosyl groups is located at the site away from the exocyclic carbon atom of $\mathrm{Cr}(\mathrm{Cr})$. (Namely, the $\mathrm{X}$ group is located at the site toward the exo-

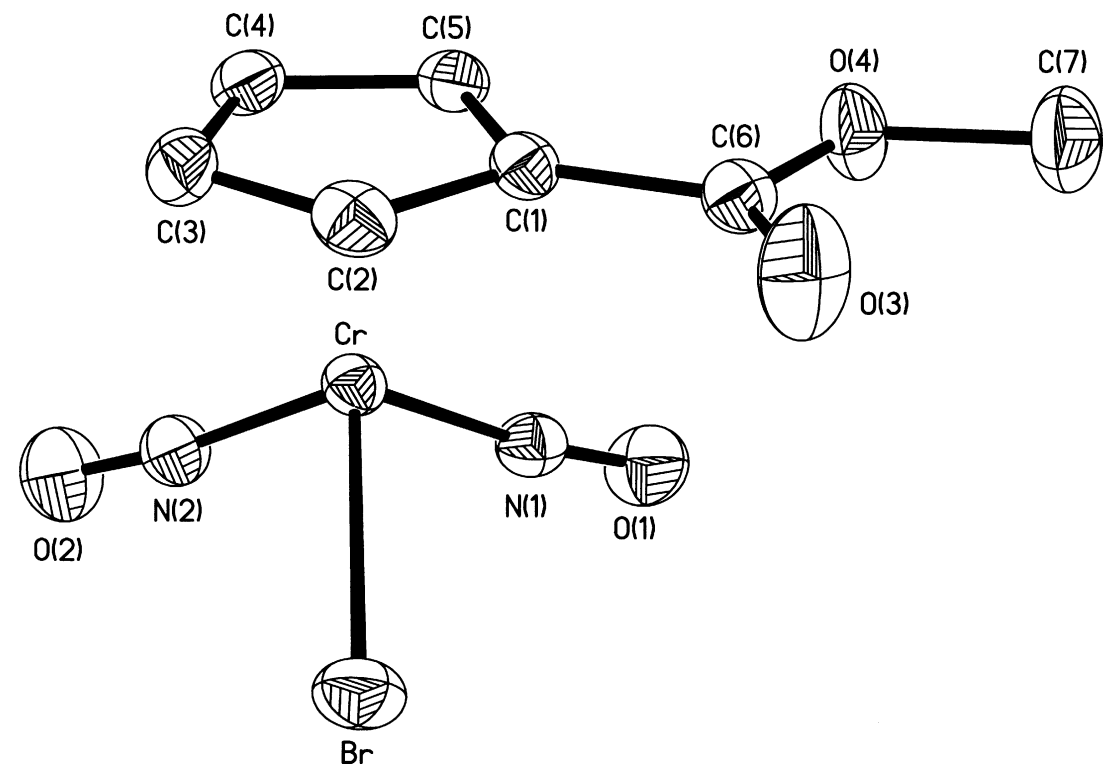

Fig. 4. Molecular configuration of $\mathbf{1 0 .}$

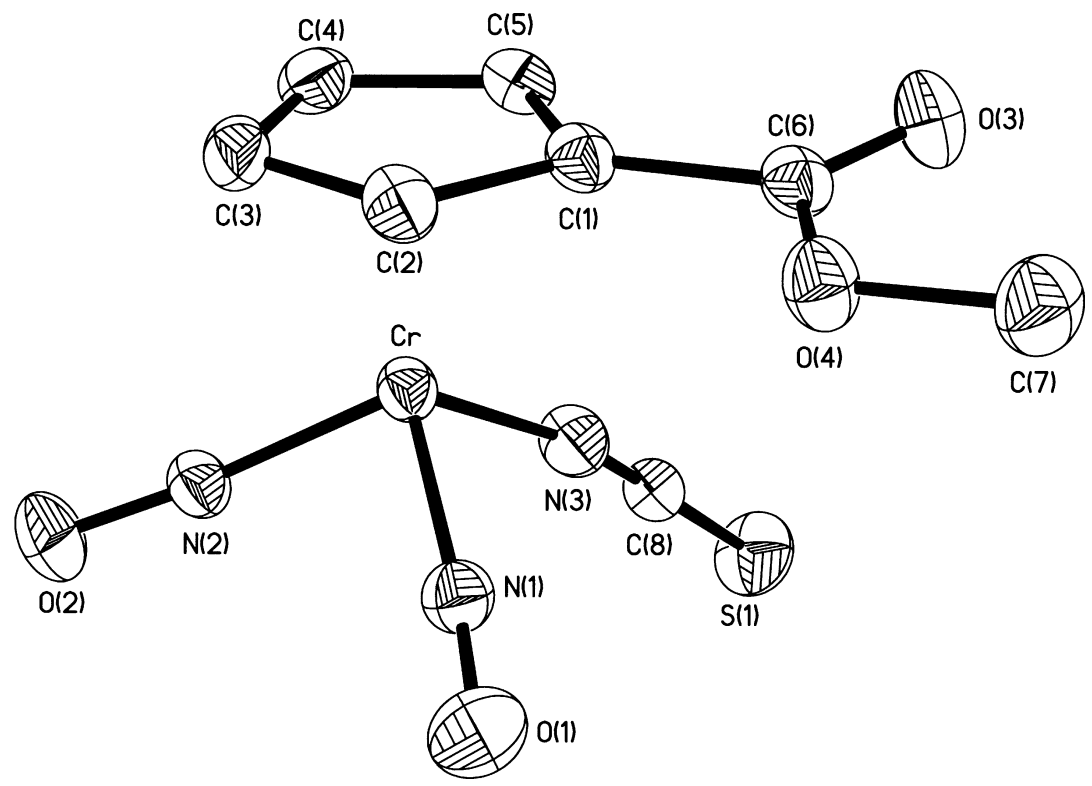

Fig. 5. Molecular configuration of $\mathbf{1 3}$. 
Table 4

Selected bond length $(\AA)$ and selected bond angles $\left(^{\circ}\right)$ for $\mathbf{1 0}$

\begin{tabular}{lc}
\hline $\mathrm{Cr}-\mathrm{C}(1)$ & \\
$\mathrm{Cr}-\mathrm{C}(2)$ & $2.205(3)$ \\
$\mathrm{Cr}-\mathrm{C}(3)$ & $2.249(3)$ \\
$\mathrm{Cr}-\mathrm{C}(4)$ & $2.229(4)$ \\
$\mathrm{Cr}-\mathrm{C}(5)$ & $2.198(3)$ \\
$\mathrm{C}(1)-\mathrm{C}(2)$ & $2.192(3)$ \\
$\mathrm{C}(1)-\mathrm{C}(5)$ & $1.410(5)$ \\
$\mathrm{C}(2)-\mathrm{C}(3)$ & $1.418(5)$ \\
$\mathrm{C}(3)-\mathrm{C}(4)$ & $1.393(5)$ \\
$\mathrm{C}(4)-\mathrm{C}(5)$ & $1.413(5)$ \\
$\mathrm{Cr}-\mathrm{N}(1)$ & $1.403(5)$ \\
$\mathrm{Cr}-\mathrm{N}(2)$ & $1.714(3)$ \\
$\mathrm{Cr}-\mathrm{Br}$ & $1.717(3)$ \\
$\mathrm{N}(1)-\mathrm{O}(1)$ & $2.4563(7)$ \\
$\mathrm{N}(2)-\mathrm{O}(2)$ & $1.153(4)$ \\
$\mathrm{C}(1)-\mathrm{C}(6)$ & $1.154(4)$ \\
$\mathrm{C}(6)-\mathrm{O}(3)$ & $1.472(5)$ \\
$\mathrm{C}(6)-\mathrm{O}(4)$ & $1.199(4)$ \\
$\mathrm{C}(7)-\mathrm{O}(4)$ & $1.324(4)$ \\
$\mathrm{Cr} . \mathrm{C}(6)$ & $1.438(5)$ \\
$\mathrm{Cr}-\mathrm{Cp}$ & 3.248 \\
$\mathrm{O}(1) \ldots \mathrm{Br}$ & 1.863 \\
$\mathrm{O}(2) \ldots \mathrm{Br}$ & 4.083 \\
$\mathrm{~N}(1)-\mathrm{Cr}-\mathrm{N}(2)$ & 4.094 \\
$\mathrm{~N}(1)-\mathrm{Cr}-\mathrm{Br}$ & $94.76(14)$ \\
$\mathrm{N}(2)-\mathrm{Cr}-\mathrm{Br}$ & $97.61(10)$ \\
$\mathrm{O}(1)-\mathrm{N}(1)-\mathrm{Cr}$ & $97.47(11)$ \\
$\mathrm{O}(2)-\mathrm{N}(2)-\mathrm{Cr}$ & $173.5(3)$ \\
$\mathrm{C}(2)-\mathrm{C}(1)-\mathrm{C}(6)$ & $172.9(3)$ \\
$\mathrm{C}(5)-\mathrm{C}(1)-\mathrm{C}(6)$ & $125.0(3)$ \\
$\mathrm{O}(3)-\mathrm{C}(6)-\mathrm{O}(4)$ & $126.9(3)$ \\
$\mathrm{O}(3)-\mathrm{C}(6)-\mathrm{C}(1)$ & $123.8(3)$ \\
$\mathrm{O}(4)-\mathrm{C}(6)-\mathrm{C}(1)$ & $124.6(3)$ \\
$\mathrm{C}(6)-\mathrm{O}(4)-\mathrm{C}(7)$ & $111.6(3)$ \\
& $117.9(3)$ \\
\hline & \\
& \\
&
\end{tabular}

cyclic carbon). In compound 10, the twist angle is $168.5^{\circ}$ (Fig. 6), and in 13, the twist angle is $172.3^{\circ}$ (Fig. 7). The twist angle is defined as the torsional angle between the nitrosyl nitrogen atom( $\mathrm{N}(2))$, the chromium atom, the $\mathrm{Cp}$ center and the ring carbon atom bearing the exocyclic carbon atom. The preference for the unsymmetrical isomer $i$ to the symmetrical isomer $i i$ may be related to the ability of the exocyclic double bond to donate electron density to the chromium atom such that it is trans to the better $\pi$-accepting ligand, i.e. $\mathrm{NO}^{+}$.

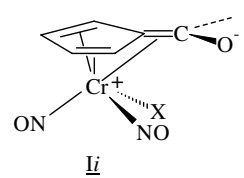

$\underline{\mathrm{I} i}$

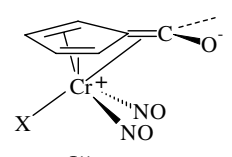

$\underline{\mathrm{I} i i}$

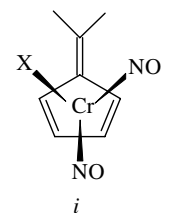

$i$

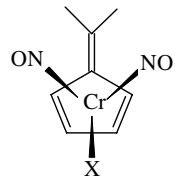

ii
As a result, the exocyclic carbons $\mathrm{C}(6)$ of $\mathbf{1 0}$ and $\mathbf{1 3}$ are bent towards the chromium atom with $\theta$ angles of $0.4^{\circ}$ and $0.6^{\circ}$, respectively. The $\theta$ angle is defined as the angle between the exocyclic $\mathrm{C}-\mathrm{C}$ bond $(\mathrm{C}(1)-\mathrm{C}(6))$ and the corresponding $\mathrm{Cp}$ ring with a positive angle toward metal and a negative angle away from the metal. The result is startling,
Table 5

Selected bond length $(\AA)$ and selected bond angles $\left({ }^{\circ}\right)$ for $\mathbf{1 3}$

\begin{tabular}{lc}
\hline $\mathrm{Cr}-\mathrm{C}(1)$ & $2.216(3)$ \\
$\mathrm{Cr}-\mathrm{C}(2)$ & $2.189(3)$ \\
$\mathrm{Cr}-\mathrm{C}(3)$ & $2.190(3)$ \\
$\mathrm{Cr}-\mathrm{C}(4)$ & $2.225(3)$ \\
$\mathrm{Cr}-\mathrm{C}(5)$ & $2.251(3)$ \\
$\mathrm{C}(1)-\mathrm{C}(2)$ & $1.427(4)$ \\
$\mathrm{C}(1)-\mathrm{C}(5)$ & $1.410(5)$ \\
$\mathrm{C}(2)-\mathrm{C}(3)$ & $1.398(5)$ \\
$\mathrm{C}(3)-\mathrm{C}(4)$ & $1.412(5)$ \\
$\mathrm{C}(4)-\mathrm{C}(5)$ & $1.397(4)$ \\
$\mathrm{Cr}-\mathrm{N}(2)$ & $1.717(2)$ \\
$\mathrm{Cr}-\mathrm{N}(1)$ & $1.717(3)$ \\
$\mathrm{Cr}-\mathrm{N}(3)$ & $1.983(3)$ \\
$\mathrm{S}(1)-\mathrm{C}(8)$ & $1.622(3)$ \\
$\mathrm{N}(1)-\mathrm{O}(1)$ & $1.158(3)$ \\
$\mathrm{N}(2)-\mathrm{O}(2)$ & $1.158(3)$ \\
$\mathrm{N}(3)-\mathrm{C}(8)$ & $1.154(4)$ \\
$\mathrm{O}(3)-\mathrm{C}(6)$ & $1.194(4)$ \\
$\mathrm{O}(4)-\mathrm{C}(6)$ & $1.334(4)$ \\
$\mathrm{O}(4)-\mathrm{C}(7)$ & $1.444(4)$ \\
$\mathrm{C}(1)-\mathrm{C}(6)$ & $1.486(4)$ \\
$\mathrm{Cr} . . \mathrm{C}(6)$ & 3.283 \\
$\mathrm{Cr}-\mathrm{Cp}$ & 1.861 \\
$\mathrm{O}(1) \ldots \mathrm{S}$ & 5.970 \\
$\mathrm{O}(2) \ldots \mathrm{S}$ & 5.860 \\
$\mathrm{~N}(1)-\mathrm{Cr}-\mathrm{N}(2)$ & $93.69(13)$ \\
$\mathrm{N}(1)-\mathrm{Cr}-\mathrm{N}(3)$ & $99.45(13)$ \\
$\mathrm{N}(2)-\mathrm{Cr}-\mathrm{N}(3)$ & $98.46(12)$ \\
$\mathrm{O}(1)-\mathrm{N}(1)-\mathrm{Cr}$ & $170.8(3)$ \\
$\mathrm{O}(2)-\mathrm{N}(2)-\mathrm{Cr}$ & $171.9(2)$ \\
$\mathrm{C}(8)-\mathrm{N}(3)-\mathrm{Cr}$ & $171.5(3)$ \\
$\mathrm{C}(6)-\mathrm{O}(4)-\mathrm{C}(7)$ & $116.1(3)$ \\
$\mathrm{C}(5)-\mathrm{C}(1)-\mathrm{C}(6)$ & $124.3(3)$ \\
$\mathrm{C}(2)-\mathrm{C}(1)-\mathrm{C}(6)$ & $128.2(3)$ \\
$\mathrm{O}(3)-\mathrm{C}(6)-\mathrm{O}(4)$ & $125.2(3)$ \\
$\mathrm{O}(3)-\mathrm{C}(6)-\mathrm{C}(1)$ & $123.5(3)$ \\
$\mathrm{O}(4)-\mathrm{C}(6)-\mathrm{C}(1)$ & $111.3(3)$ \\
$\mathrm{N}(3)-\mathrm{C}(8)-\mathrm{S}(1)$ & $178.2(3)$ \\
\hline &
\end{tabular}

Table 6

Atomic coordinates $\left(\times 10^{4}\right)$ and equivalent isotropic displacement parameters $\left(\AA^{2} \times 10^{3}\right)$ for $\mathbf{1 0}$

\begin{tabular}{lrrrr}
\hline & \multicolumn{1}{l}{$y$} & \multicolumn{1}{l}{$z$} & $U_{\text {(eq) }}$ \\
\hline $\mathrm{Cr}$ & $3849(1)$ & $1522(1)$ & $2448(1)$ & $33(1)$ \\
$\mathrm{Br}$ & $746(1)$ & $2104(1)$ & $2768(1)$ & $56(1)$ \\
$\mathrm{N}(1)$ & $3616(4)$ & $1354(2)$ & $381(4)$ & $41(1)$ \\
$\mathrm{N}(2)$ & $5169(4)$ & $2293(2)$ & $2236(4)$ & $44(1)$ \\
$\mathrm{C}(1)$ & $3381(5)$ & $413(2)$ & $3320(4)$ & $37(1)$ \\
$\mathrm{C}(2)$ & $3087(6)$ & $874(2)$ & $4662(4)$ & $45(1)$ \\
$\mathrm{C}(3)$ & $4779(6)$ & $1243(2)$ & $5018(4)$ & $48(1)$ \\
$\mathrm{C}(4)$ & $6153(5)$ & $1004(2)$ & $3921(5)$ & $46(1)$ \\
$\mathrm{C}(5)$ & $5300(5)$ & $488(2)$ & $2871(4)$ & $40(1)$ \\
$\mathrm{C}(6)$ & $1932(5)$ & $-70(2)$ & $2565(4)$ & $41(1)$ \\
$\mathrm{C}(7)$ & $1401(7)$ & $-976(2)$ & $550(6)$ & $70(1)$ \\
$\mathrm{O}(1)$ & $3585(4)$ & $1190(2)$ & $-984(3)$ & $60(1)$ \\
$\mathrm{O}(2)$ & $6219(5)$ & $2766(2)$ & $2102(4)$ & $71(1)$ \\
$\mathrm{O}(3)$ & $331(4)$ & $-125(2)$ & $3006(4)$ & $80(1)$ \\
$\mathrm{O}(4)$ & $2620(4)$ & $-447(1)$ & $1341(4)$ & $56(1)$ \\
\hline
\end{tabular}

$U_{\text {(eq) }}$ is defined as one-third of the trace of the orthogonalized $U_{i j}$ tensor. 
Table 7

Atomic coordinates $\left(\times 10^{4}\right)$ and equivalent isotropic displacement parameters $\left(\AA^{2} \times 10^{3}\right)$ for $\mathbf{1 3}$

\begin{tabular}{llrrl}
\hline & $x$ & \multicolumn{1}{l}{$y$} & \multicolumn{1}{l}{$z$} & $U_{(\mathrm{eq})}$ \\
\hline $\mathrm{Cr}$ & $4225(1)$ & $1179(1)$ & $2116(1)$ & $33(1)$ \\
$\mathrm{S}(1)$ & $9031(2)$ & $-3363(1)$ & $2304(1)$ & $62(1)$ \\
$\mathrm{N}(1)$ & $3093(4)$ & $743(3)$ & $3870(3)$ & $42(1)$ \\
$\mathrm{N}(2)$ & $2467(4)$ & $462(3)$ & $1561(3)$ & $38(1)$ \\
$\mathrm{N}(3)$ & $6426(4)$ & $-599(3)$ & $2132(3)$ & $45(1)$ \\
$\mathrm{O}(1)$ & $2169(4)$ & $639(3)$ & $5010(3)$ & $69(1)$ \\
$\mathrm{O}(2)$ & $1155(4)$ & $154(3)$ & $1166(3)$ & $59(1)$ \\
$\mathrm{O}(3)$ & $8969(3)$ & $2617(3)$ & $2974(3)$ & $54(1)$ \\
$\mathrm{O}(4)$ & $6041(3)$ & $3261(3)$ & $4375(3)$ & $51(1)$ \\
$\mathrm{C}(1)$ & $5875(4)$ & $3045(3)$ & $2116(3)$ & $37(1)$ \\
$\mathrm{C}(2)$ & $3757(5)$ & $3602(4)$ & $2177(4)$ & $42(1)$ \\
$\mathrm{C}(3)$ & $3223(5)$ & $3503(4)$ & $924(4)$ & $48(1)$ \\
$\mathrm{C}(4)$ & $4977(5)$ & $2895(4)$ & $81(4)$ & $47(1)$ \\
$\mathrm{C}(5)$ & $6604(5)$ & $2631(4)$ & $807(4)$ & $41(1)$ \\
$\mathrm{C}(6)$ & $7162(5)$ & $2936(4)$ & $3183(4)$ & $40(1)$ \\
$\mathrm{C}(7)$ & $7149(6)$ & $3304(5)$ & $5449(4)$ & $62(1)$ \\
$\mathrm{C}(8)$ & $7519(5)$ & $-1744(4)$ & $2220(3)$ & $39(1)$ \\
\hline
\end{tabular}

$U_{\text {(eq) }}$ is defined as one-third of the trace of the orthogonalized $U_{i j}$ tensor.

since it overthrows the concept that cyclopentadienyl groups with the powerful electron-withdrawing groups have them oriented trans to the NO ligand [19].

It is interesting to find out that the contribution of canonical form I $i$ to I to some extent was revealed by the carbon-carbon bond lengths in the cyclopentadienyl ring. The shorter bond lengths in $\AA$ of $\mathrm{C}(2)-\mathrm{C}(3)$ (1.393(5), $1.398(5))$ and $\mathrm{C}(4)-\mathrm{C}(5)(1.403(5), 1.397(4))$, and longer bond lengths of $\mathrm{C}(1)-\mathrm{C}(2)(1.410(5), 1.427(4)), \mathrm{C}(3)-\mathrm{C}(4)$ (1.413(5), 1.412(5)) and $\mathrm{C}(1)-\mathrm{C}(5)(1.418(5), 1.410(5))$ were obtained in both cases of $\mathbf{1 0}$ and $\mathbf{1 3}$.

In 13, the chromium-isothiocyanate fragment is approximately linear, with $\mathrm{Cr}-\mathrm{N}-\mathrm{C}$ and $\mathrm{N}-\mathrm{C}-\mathrm{S}$ angles of $171.5(3)^{\circ}$ and $178.2(3)^{\circ}$, respectively. Given that the metal-N-C angle is linear, a predominant weight was assigned to canonical form iii and a relatively insignificant weight to $i v[20]$.

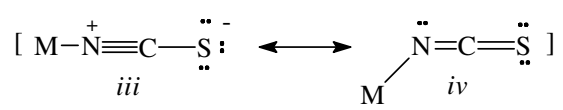

In view of the shortness of the $\mathrm{Cr}-\mathrm{N}$ (nitrosyl) distances (in $\AA$ ) $(\mathrm{Cr}-\mathrm{N}(1), 1.717(3)$; $\mathrm{Cr}-\mathrm{N}(2), 1.717(2))$ relative to $\mathrm{Cr}-\mathrm{N}$ (isothiocyanato) $(\mathrm{Cr}-\mathrm{N}(3), 1.983(3))$ for compound 13, appreciable $\mathrm{d} \pi$ back-donation from chromium atom into the $\pi^{*}$ orbitals of nitrosyl group is demonstrated. And it appears that the canonical form vi rather than $v$ has a greater extent of contribution to the chromiumnitrosyl

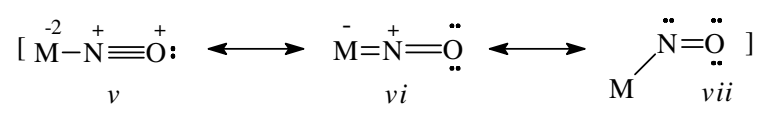

bonding. And the less contribution of vii than vi was reflected by the angles of $\mathrm{Cr}-\mathrm{N}-\mathrm{O}$ of ca. $171^{\circ}(\mathrm{Cr}-\mathrm{N}(1)$ $\left.\mathrm{O}(1), 170.8(3)^{\circ}, \mathrm{Cr}-\mathrm{N}(2)-\mathrm{O}(2), 171.9(2)^{\circ}\right)$. These values are similar to those found in $9\left(171.2(5)^{\circ}, 172.1(4)^{\circ}\right)$ and $11\left(176.0(5)^{\circ}\right.$ and $\left.174.3(4)^{\circ}\right)$, respectively [5].

\section{Experimental details}

All the syntheses were carried out under nitrogen by the use of Schlenk techniques. Traces of oxygen in the nitrogen were removed with BASF catalyst and deoxygenated nitrogen was dried over molecular sieves $(3 \AA)$ and $\mathrm{P}_{2} \mathrm{O}_{5}$. Hexane, pentane, benzene, and dichloromethane were dried over calcium hydride and freshly distilled under nitrogen. Diethyl ether was dried over sodium and redistilled under

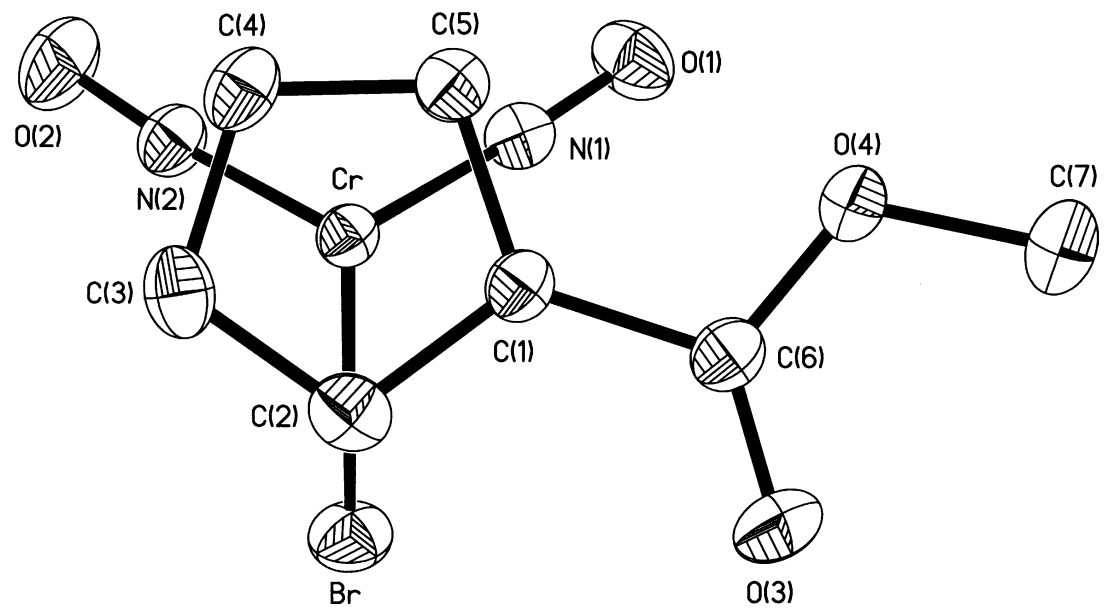

Fig. 6. View of $\mathbf{1 0}$ along the normal of $\mathrm{Cp}(\mathrm{Cr})$ ring. 


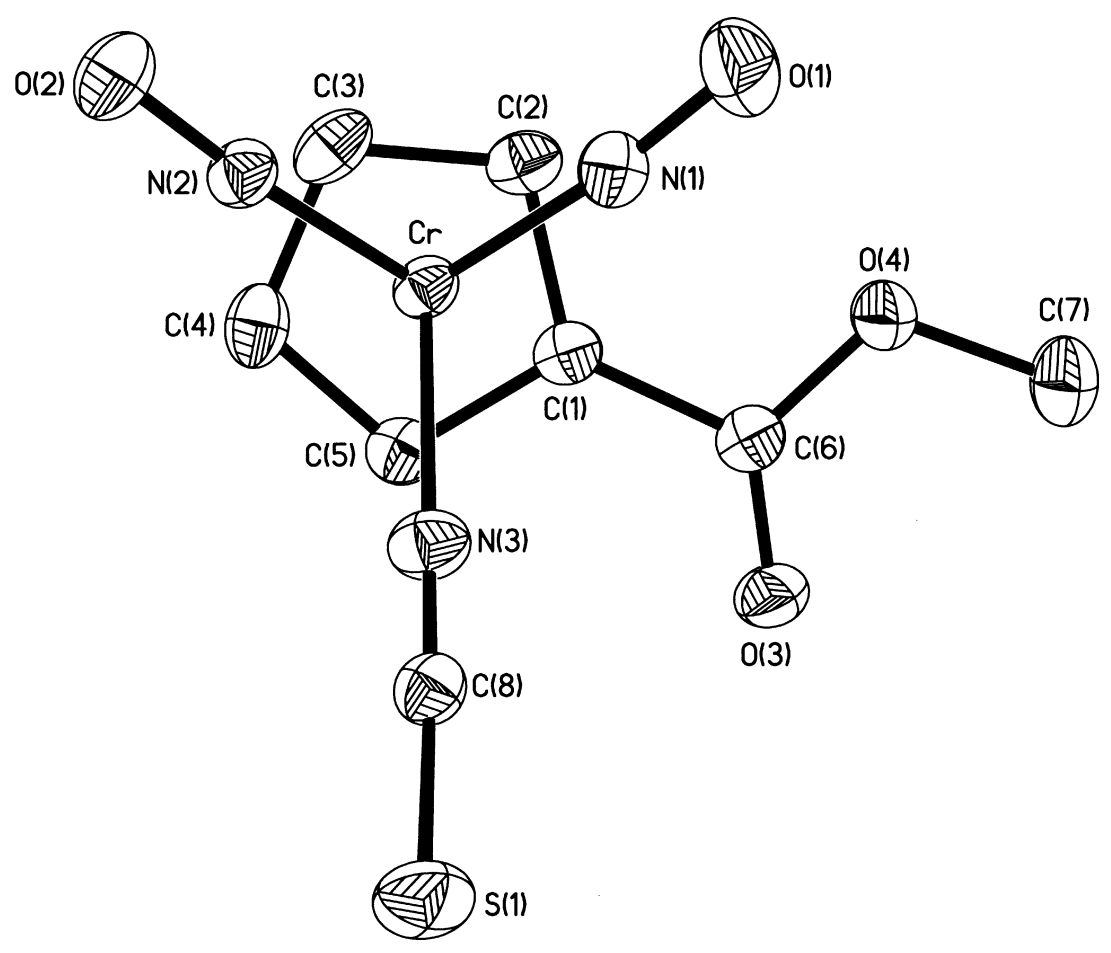

Fig. 7. View of $\mathbf{1 3}$ along the normal of $\mathrm{Cp}(\mathrm{Cr})$ ring.

nitrogen from sodium-benzophenone ketyl. All the other solvents were used as commercially obtained.

Column chromatography was carried out under nitrogen with Merck Kiesel-gel 60. The silica gel was heated with a heat gun during mixing in a rotary evaporator attached to a vacuum pump for $1 \mathrm{~h}$ to remove water and oxygen. The silica gel was then stored under nitrogen until use. Compounds 17 [9] and 18, were prepared according to the literature procedures [16].

${ }^{1} \mathrm{H}$ and ${ }^{13} \mathrm{C}$ NMR were acquired on a Varian Unity-300 spectrometer. Chemical shifts were referenced to tetramethylsilane. IR spectra were recorded a Perkin-Elmer Fourier transform IR 1725X spectrophotomer. Microanalyses were carried out by the Microanalytic Laboratory of the National Chung Hsing University.

\subsection{Preparation of bromo $\left(\eta^{5}\right.$-carbomethoxycyclopentadienyl) dinitrosylchromium (10)}

Through a solution of ( $\eta^{5}$-Carbomethoxycyclopentadienyl)dicarbonylnitrosylchromium (8) $(2.25 \mathrm{~g}, 8.65 \mathrm{mmol})$ in $20 \mathrm{ml}$ of isopropanol, hydrogen bromide was bubbled for $5 \mathrm{~min}$. After cooling to $0-10^{\circ} \mathrm{C}$ with stirring for $15 \mathrm{~min}$ (orange red solution resulted), isoamyl nitrite $(2.2 \mathrm{ml}$, $16.36 \mathrm{mmol}$ ) was added slowly. Carbon oxide evolved and the solution changed to dark green abruptly. The reaction mixture was continued to stir for $1 \mathrm{~h}$. The solvent was removed. The residue was extracted with $100 \mathrm{ml}$ of dichloromethane. The extract was washed several times with distilled water until the aqueous layer gave an light yellow color and dried with magnesium sulfate. The solution was filtered and concentrated to dark-green solid. The solid was dissolved in $25 \mathrm{ml}$ of dichloromethane. Five grams of silica gel were added and the solvent was then removed under vacuum. The residue was added to a dry-packed column $(2.0 \times 10 \mathrm{~cm})$ of silica gel. Elution of the column with hexane/ether (2:1) gave an brownish green layer which upon removal of the solvent gave bromo $\left(\eta^{5}\right.$-carbomethoxycyclopentadienyl)dinitrosylchromium (10) (2.29 g, 84\%). An Xray sample (elongated gleamy blackish brown crystal) was prepared by recrystallization using the solvent expansion method from hexane:dichloromethane $(8: 3)$ at $0{ }^{\circ} \mathrm{C}$ for $48 \mathrm{~h}$.

Anal. Calc. for $\mathrm{C}_{7} \mathrm{H}_{7} \mathrm{O}_{4} \mathrm{~N}_{2} \mathrm{BrCr}$ : C, 26.68; H, 2.24; N, 8.89. Found: C, 26.80; H, 2.37; N, 8.44\%. Proton NMR $\left(\mathrm{CDCl}_{3}\right): \delta$ (relative intensity, multiplicity, assignment): $3.87\left(3 \mathrm{H}, \mathrm{s},-\mathrm{OCH}_{3}\right) ; 5.79(2 \mathrm{H}, \mathrm{t}, \mathrm{Cp} \mathrm{H}(3,4)) ; 6.26(2 \mathrm{H}, \mathrm{t}$, Cp $\mathrm{H}(2,5))$. Carbon-13 NMR $\left(\mathrm{CDCl}_{3}\right): \delta$ (assignment): $52.82\left(-\mathrm{OCH}_{3}\right) ; 102.56(\mathrm{Cp}, \mathrm{C}(1)) ; 103.65(\mathrm{Cp}, \mathrm{C}(3,4))$; $105.56(\mathrm{Cp}, \mathrm{C}(2,5)) ; 161.99\left(-\mathrm{COOCH}_{3}\right)$. IR $(\mathrm{KBr}): v$ $\left(\mathrm{cm}^{-1}\right)$ (intensity): $3082(\mathrm{~s}), 1826(\mathrm{vs}), 1731(\mathrm{bvs}), 1475(\mathrm{~s})$, 1424 (s), 1293(s), 1149(s), 858(s), 776 (s). Mass spectrum: $\mathrm{m} / \mathrm{z} 315\left(\mathrm{M}^{+}\right)$.

\subsection{Preparation of ( $\eta^{5}$-carbomethoxycyclopentadienyl) (isothiocyanato) dinitrosylchromium (13)}

To a solution of ( $\eta^{5}$-carbomethoxycyclopentadienyl)chlorodinitrosylchromium (9) $(0.13 \mathrm{~g}, 0.48 \mathrm{mmol})$ in $20 \mathrm{ml} \mathrm{H}_{2} \mathrm{O} 5 \mathrm{ml} \mathrm{CH}{ }_{3} \mathrm{OH}$, silver nitrate $(0.09 \mathrm{~g}, 0.60 \mathrm{mmol})$ was added. The solution was stirred for $30 \mathrm{~min}$ at room temperature, followed by filtration to remove silver chlo- 
ride. To the filtrate, potassium thiocyanate $(0.09 \mathrm{~g}$, $0.96 \mathrm{mmol}$ ) was added and the reaction mixture was stirred for $8 \mathrm{~h}$ at room temperature. The reaction mixture was then extracted with dichloromethane. The extract was washed three times with distilled water and dried with anhydrous magnesium sulfate. The solution was filtered. Twenty grams of silica gel were added to the solution, and the solvent was then removed under vacuum. The residue was added to a dry-packed column $(2.0 \times 10 \mathrm{~cm})$ of silical gel. Elution of the column with hexane:ether (3:1) gave a dark green band which upon removal of the solvent gave $\left(\eta^{5}\right.$-carbomethoxycyclopentadienyl)(isothiocyanato)dinitrosylchromium (13) $(0.07 \mathrm{~g},(50 \%))$ as a dark green solid. An X-ray sample (granular blackish brown crystal) was prepared by recrystallization using the solvent expansion method from hexane:chloroform $(8: 3)$ at $0{ }^{\circ} \mathrm{C}$ for $48 \mathrm{~h}$.

Anal. Calc. for $\mathrm{C}_{8} \mathrm{H}_{7} \mathrm{O}_{4} \mathrm{~N}_{3} \mathrm{SCr}: \mathrm{C}, 32.77 ; \mathrm{H}, 2.41 ; \mathrm{N}$, 14.33. Found: C, 33.28; H, 2.66 N, 14.08\%. Proton NMR $\left(\mathrm{CDCl}_{3}\right): \delta$ (relative intensity, multiplicity, assignment): $3.92\left(-\mathrm{OCH}_{3}\right) ; 5.77(2 \mathrm{H}, \mathrm{t}, \mathrm{Cp} \mathrm{H}(3,4)) ; 6.26(2 \mathrm{H}, \mathrm{t}, \mathrm{Cp}$ $\mathrm{H}(2,5))$. Carbon-13 NMR $\left(\mathrm{CDCl}_{3}\right): \delta$ (assignment): 53.19 $\left(-\mathrm{OCH}_{3}\right) ; 92.39(\mathrm{Cr}-\mathrm{NCS}) ; 103.12(\mathrm{Cp}, \mathrm{C}(3,4)) ; 104.25$ $(\mathrm{Cp}, \mathrm{C}(1)) ; 105.33(\mathrm{Cp}, \mathrm{C}(2,5)) ; 161.41 \quad\left(-\mathrm{COOCH}_{3}\right)$. $\operatorname{IR}(\mathrm{KBr}): v\left(\mathrm{~cm}^{-1}\right)$ (intensity): 2112(s), 1839(s), 1723(bvs), 1425(m), 1297(s), 1153(s), 845(m), 584(m). Mass spectrum: $\mathrm{m} / \mathrm{z} 293\left(\mathrm{M}^{+}\right)$.

\subsection{Preparation of ( $\eta^{5}$-carbomethoxycyclopentadienyl) (isoselenocyanato) dinitrosylchromium (14)}

To a solution of $\left(\eta^{5}\right.$-carbomethoxycyclopentadienyl)chlorodinitrosylchromium $(8)(0.13 \mathrm{~g}, 0.48 \mathrm{mmol})$ in $20 \mathrm{ml} \mathrm{H}_{2} \mathrm{O} 5 \mathrm{ml} \mathrm{CH} \mathrm{CH}_{3} \mathrm{OH}$, silver nitrate $(0.1 \mathrm{~g}, 0.60 \mathrm{mmol})$ was added. The solution was stirred for $30 \mathrm{~min}$ at room temperature, followed by filtration to remove silver chloride. To the filtrate, potassium selenocyanate $(0.14 \mathrm{~g}$, $0.96 \mathrm{mmol}$ ) was added and the reaction mixture was stirred for $12 \mathrm{~h}$ at room temperature. The reaction mixture was then extracted with dichloromethane. The extract was washed three times with distilled water and dried with anhydrous magnesium sulfate. The solution was filtered. Twenty grams of silica gel were added to the solution, and the solvent was then removed under vacuum. The residue was added to a dry-packed column $(2.0 \times 10 \mathrm{~cm})$ of silical gel. Elution of the column with dichloromethane gave a green band which upon removal of the solvent gave $\left(\eta^{5}\right.$-carbomethoxycyclopentadienyl)(isoselenocyanato)dinitrosylchromium (14) $(0.08 \mathrm{~g}$, $(49 \%))$ as a green solid.

Anal. Calc. for $\mathrm{C}_{8} \mathrm{H}_{7} \mathrm{O}_{4} \mathrm{~N}_{3} \mathrm{SeCr}: \mathrm{C}, 28.25 ; \mathrm{H}, 2.07 ; \mathrm{N}$, 12.36. Found: C, $28.75 ; \mathrm{H}, 2.40 \mathrm{~N}, 12.65 \%$. Proton NMR $\left(\mathrm{CDCl}_{3}\right): \delta$ (relative intensity, multiplicity, assignment): $3.88\left(-\mathrm{OCH}_{3}\right) ; 5.75(2 \mathrm{H}, \mathrm{t}, \mathrm{Cp} \mathrm{H}(3,4)) ; 6.25(2 \mathrm{H}, \mathrm{t}, \mathrm{Cp}$ $\mathrm{H}(2,5))$. Carbon-13 NMR $\left(\mathrm{CDCl}_{3}\right): \delta$ (assignment): 52.96 $\left(-\mathrm{OCH}_{3}\right) ; 100.91(\mathrm{Cp}, \mathrm{C}(3,4)) ; 102.40(\mathrm{Cp}, \mathrm{C}(2,5)) ; 102.64$ (Cp, C(1)); 138.89 (Cr-NCSe); $161.88\left(-\mathrm{COOCH}_{3}\right)$. IR $(\mathrm{KBr}): \quad v\left(\mathrm{~cm}^{-1}\right)$ (intensity): 3398(bs), 2163(w),1844(s), 1734(bvs), 1302(s), 1097(s), 620(s). Mass spectrum: $\mathrm{m} / \mathrm{z}$ $340\left(\mathrm{M}^{+}\right)$.

\subsection{Preparation of bromo $\left(\eta^{5}\right.$-carboxycyclopentadienyl $)$ dinitrosylchromium (15)}

Through a solution of ( $\eta^{5}$-carboxycyclopentadienyl)dicarbonylnitrosylchromium (17) $(2.49 \mathrm{~g}, 9.56 \mathrm{mmol})$ in $30 \mathrm{ml}$ of isopropanol, hydrogen bromide was bubbled for $5 \mathrm{~min}$. After cooling to $0-10{ }^{\circ} \mathrm{C}$ with stirring for $20 \mathrm{~min}$ (orange red solution resulted), isoamyl nitrite $(2.6 \mathrm{ml}, 19.12 \mathrm{mmol})$ was added slowly. Carbon oxide evolved and the solution changed to dark green subsequently. The reaction mixture was continued to stir for $1 \mathrm{~h}$. After concentration of the solution to $10 \mathrm{ml}, 30 \mathrm{ml}$ of dichloromethane was added, a large quantity of dark green solid precipitated out. The solid was obtained through frit filtration and were washed several times with distilled water. Compound bromo $\left(\eta^{5}\right.$-carboxycyclopentadienyl)dinitrosylchromium (15) $\quad(2.24 \mathrm{~g}, \quad 74 \%)$ was obtained after vacuum drying. An X-ray sample (granular blackish brown crystal) was prepared by recrystallization using the solvent expansion method from hexane:tetrahydrofuran (5:2) at $0{ }^{\circ} \mathrm{C}$ for $48 \mathrm{~h}$.

Anal. Calc. for $\mathrm{C}_{6} \mathrm{H}_{5} \mathrm{O}_{4} \mathrm{~N}_{2} \mathrm{BrCr}$ : C, 23.94; H, 1.68; N, 9.31. Found: C, 24.04; H, 1.73; N, 8.77\%. Proton NMR $\left(\mathrm{CD}_{3} \mathrm{COCD}_{3}\right): \delta$ (relative intensity, multiplicity, assignment): 6.02 (2H, t, $\mathrm{Cp} \mathrm{H}(3,4))$; 6.41 (2H, t, $\mathrm{Cp} \mathrm{H}(2,5))$. Carbon-13 NMR $\left(\mathrm{CD}_{3} \mathrm{COCD}_{3}\right): \delta$ (assignment): $107.98(\mathrm{Cp}$, $\mathrm{C}(1)) ; 104.42$ (Cp, C(3,4)); 107.88 (Cp, C(2,5)). IR (KBr): $v\left(\mathrm{~cm}^{-1}\right)$ (intensity): $3109-2368(\mathrm{~m}$, broad $), 1832(\mathrm{vs})$, 1730(vs), 1683 (vs), 1486 (s), 1304 (s), 1178(s), 858 (s), 587 (s). Mass spectrum: $\mathrm{m} / z 315\left(\mathbf{M}^{+}\right)$.

\subsection{Preparation of ( $\eta^{5}$-benzoylcyclopentadienyl) bromodinitrosylchromium (16)}

Through a solution of ( $\eta^{5}$-benzoylcyclopentadienyl)dicarbonylnitrosylchromium (18) $(1.23 \mathrm{~g}, 4 \mathrm{mmol})$ in $50 \mathrm{ml}$ of isopropanol, hydrogen bromide was bubbled for $5 \mathrm{~min}$. After cooling to $0-10{ }^{\circ} \mathrm{C}$ with stirring for $15 \mathrm{~min}$ (orange red solution resulted), isoamyl nitrite $(2.0 \mathrm{ml}, 14.48 \mathrm{mmol})$ was added slowly. Carbon oxide evolved and the solution changed to dark green subsequently. The reaction mixture was continued to stir for $1 \mathrm{~h}$. The solvent was removed. The residue was extracted with $100 \mathrm{ml}$ of dichloromethane. The extract was washed several times with distilled water until the aqueous layer gave a light yellow color and dried with magnesium sulfate. The solution was filtered and concentrated to dark-green solid. The solid was dissolved in $25 \mathrm{ml}$ of dichloromethane. Five grams of silica gel were added and the solvent was then removed under vacuum. The residue was added to a dry-packed column $(1.8 \times 9 \mathrm{~cm})$ of silica gel. Elution of the column with hexane/ether (3:1) gave an brownish green layer which upon removal of the solvent gave $\left(\eta^{5}\right.$-benzoylcyclopentadienyl)bromodinitrosylchromium (16) $(1.24 \mathrm{~g}, 90 \%)$. An 
X-ray sample (granular gleamy blackish brown crystal) was prepared by recrystallization using the solvent expansion method from hexane:dichloromethane $(5: 2)$ at $0{ }^{\circ} \mathrm{C}$ for $48 \mathrm{~h}$.

Anal. Calc. for $\mathrm{C}_{12} \mathrm{H}_{9} \mathrm{O}_{3} \mathrm{~N}_{2} \mathrm{BrCr}$ : C, 39.91; H, 2.51; N, $7.76 \%$. Proton NMR $\left(\mathrm{CDCl}_{3}\right): \delta$ (relative intensity, multiplicity, assignment): $5.88(2 \mathrm{H}, \mathrm{t}, \mathrm{Cp} \mathrm{H}(3,4)) ; 6.32(2 \mathrm{H}, \mathrm{t}$, Cp $\mathrm{H}(2,5)) ; 7.51(2 \mathrm{H}, \mathrm{t}, \mathrm{Ph} \mathrm{H}(3,5)) ; 7.60(1 \mathrm{H}, \mathrm{t}, \mathrm{Ph}$ $\mathrm{H}(4)) ; 7.85$ (2H, d, $\mathrm{Ph} \mathrm{H}(2,6))$. Carbon-13 NMR $\left(\mathrm{CDCl}_{3}\right)$ : $\delta$ (assignment): $103.35(\mathrm{Cp}, \mathrm{C}(3,4)) ; 106.64(\mathrm{Cp}, \mathrm{C}(2,5))$; 107.49 (Cp, C(1)); $128.75(\mathrm{Ph}, \mathrm{C}(3,5))$; $128.83(\mathrm{Ph}, \mathrm{C}(2,6))$; 133.36 (Ph, C(4)); 136.91 (Ph, C(1)); 188.41 (-C(O)-). IR $(\mathrm{KBr}): v\left(\mathrm{~cm}^{-1}\right)$ (intensity): 1828(vs), 1739(vs), 1643(s), 1287(s), 853(s). Mass spectrum: $m / z 361\left(\mathrm{M}^{+}\right)$.

\subsection{X-ray diffraction analyses of $\mathbf{1 0}$ and $\mathbf{1 3}$}

The intensity data were collected on a CAD- 4 diffractometer with a graphite monochromator (Mo $\mathrm{K} \alpha$ radiation) for compound 10; on SMART-CCD diffractometer using $\omega$ scan for compound 13. $\theta-2 \theta$ scan data were collected at room temperature $\left(24^{\circ} \mathrm{C}\right)$. The data were corrected for absorption, Lorentz and polarization effects. The absorption correction is according to the empirical psi rotation. The details of crystal data and intensity collec-

Table 8

Selected crystal data and refinement parameters for $\mathbf{1 0}$

\begin{tabular}{ll}
\hline Empirical formula & $\mathrm{C}_{7} \mathrm{H}_{7} \mathrm{BrN}_{2} \mathrm{O}_{4} \mathrm{Cr}$ \\
Formula weight $(\mathrm{g} / \mathrm{mol})$ & 315.06 \\
Temperature $(\mathrm{K})$ & $293(2)$ \\
Wavelength $(\AA)$ & 0.71073 \\
Crystal system & Monoclinic \\
Space group & $P 2(1) / n$ \\
Unit cell dimensions & \\
$a(\AA)$ & $7.0276(8)$ \\
$b(\AA)$ & $18.5427(14)$ \\
$c(\AA)$ & $8.1481(7)$ \\
$\beta\left({ }^{\circ}\right)$ & $92.231(8)$ \\
Volume $\left(\AA^{3}\right)$ & $1060.98(17)$ \\
$Z$ & 4 \\
$D_{\text {calc }}\left(\mathrm{Mg} / \mathrm{m}^{3}\right)$ & 1.972 \\
Absorption coefficient $\left(\mathrm{mm}^{-1}\right)$ & 4.839 \\
$F(000)$ & 616 \\
Crystal size (mm $\left.{ }^{3}\right)$ & $0.50 \times 0.25 \times 0.22$ \\
$\theta$ Range for data collection $\left({ }^{\circ}\right)$ & $2.20-27.50$ \\
Index ranges & $-9 \leqslant h \leqslant 9,0 \leqslant k \leqslant 24$, \\
& $0 \leqslant l \leqslant 10$ \\
Reflections collected & 2439 \\
Independent reflections $\left[R_{\text {int }}\right]$ & $2439[0.0000]$ \\
Completeness to $\theta=27.50^{\circ}$ & $100.0 \%$ \\
Absorption correction & $\Psi$-scan \\
Maximum and minimum transmission & 0.3155 and 0.2727 \\
Refinement method full-matrix least- & \\
$\quad$ squares on $F^{2}$ & \\
Data/restraints/parameters & $2439 / 0 / 137$ \\
Goodness-of-fit on $F^{2}$ & 1.010 \\
Final $R$ indices $[I>2 \sigma(I)]$ & $R_{1}=0.0337, w R_{2}=0.0876$ \\
$R$ indices (all data) & $R_{1}=0.0664, w R_{2}=0.0966$ \\
Extinction coefficient & $0.0026(8)$ \\
Largest difference in peak & 0.418 and -0.624 \\
and hole $\left(\mathrm{e} \AA^{-3}\right)$ & \\
\hline & \\
\hline &
\end{tabular}

Table 9

Selected crystal data and refinement parameters for $\mathbf{1 3}$

\begin{tabular}{ll}
\hline Empirical formula $\mathrm{C}_{8} \mathrm{H}_{7} \mathrm{~N}_{3} \mathrm{O}_{4} \mathrm{SCr}$ & \\
Formula weight $(\mathrm{g} / \mathrm{mol})$ & 293.23 \\
Temperature $(\mathrm{K})$ & $295(2)$ \\
Wavelength $(\AA)$ & 0.71073 \\
Crystal system & Triclinic \\
Space group & $P \overline{1}$ \\
Unit cell dimensions & \\
$a(\AA)$ & $6.8128(4)$ \\
$b(\AA)$ & $9.1295(6)$ \\
$c(\AA)$ & $9.9184(7)$ \\
$\alpha\left({ }^{\circ}\right)$ & $74.3400(10)$ \\
$\beta\left({ }^{\circ}\right)$ & $77.5200(10)$ \\
$\gamma\left({ }^{\circ}\right)$ & $78.787(2)$ \\
Volume $\left(\AA^{3}\right)$ & $573.85(6)$ \\
$Z$ & 2 \\
$D_{\text {calc }}\left(\mathrm{Mg} / \mathrm{m}^{3}\right)$ & 1.697 \\
Absorption coefficient $\left(\mathrm{mm}^{-1}\right)$ & 1.184 \\
$F(000)$ & 296 \\
Crystal size (mm & \\
$\theta$ Range for data collection $\left(^{\circ}\right)$ & $0.20 \times 0.12 \times 0.04$ \\
Index ranges & $2.17-26.37$ \\
& $-8 \leqslant h \leqslant 8,-11 \leqslant k \leqslant 11$, \\
Reflections collected & $-12 \leqslant l \leqslant 12$ \\
Independent reflections $\left[R_{\text {int }}\right]$ & 5433 \\
Completeness to $\theta=26.37^{\circ}$ & $2273[0.0353]$ \\
Absorption correction & $96.5 \%$ \\
& Semi-empirical from \\
Maximum and minimum transmission & 0.8944 and 0.7368 \\
Refinement method full-matrix least- & \\
$\quad$ squares on $F^{2}$ & \\
Data/restraints/parameters & $2273 / 0 / 155$ \\
Goodness-of-fit on $F^{2}$ & 1.034 \\
Final $R$ indices $[I>2 \sigma(I)]$ & $R_{1}=0.0436, w R_{2}=0.0898$ \\
$R$ indices $($ all data) & $R_{1}=0.0646, w R_{2}=0.0973$ \\
Largest difference in peak and hole & 0.296 and -0.385 \\
$\quad\left(\mathrm{e} \AA^{-3}\right)$ & \\
\hline & \\
& \\
&
\end{tabular}

tion are summarized in Tables 8 and 9 for compounds $\mathbf{1 0}$ and $\mathbf{1 3}$, respectively.

The structures were solved by direct methods and were refined by full matrix least squares refinement based on $F$ values. All of the non-hydrogen atoms were refined with anisotropic thermal parameters. All of the hydrogen atoms were positioned at calculated coordinate with a fixed isotropic thermal parameter $\left(U=U(\right.$ attached atom $\left.)+0.01 \AA^{2}\right)$. Atomic scattering factors and corrections for anomalous dispersion were from International Tables for X-ray Crystallography [17]. All calculations were performed on a PC computer using SHELEX software package [18].

\subsection{Computational method}

Here, we use unrestricted B3LYP hybrid method involving the three-parameter Becke exchange functional [21] and a Lee-Yang-Parr correlation functional [22]. All calculations are performed using GAUSSIAN-03 program [23]. The geometries for $\mathbf{1 0}$ and $\mathbf{1 3}$ are taken from the crystallographic data. The atomic charges have been analyzed using the natural population analysis (NPA) which yields reliable atomic charges and natural bond orbital (NBO) calcula- 
tions [24]. An important feature of the NBO method is that the presence of diffuse functions in the basis sets does not affect the results.

\section{Acknowledgements}

The authors are grateful to the National Science Council of Taiwan for grants in supports of this research program and the computational resources provided National Center for High-Performance Computing.

\section{References}

[1] (a) Comprehensive Organometallic Chemistry II (vols. 5 and 7), III (vols. 5 and 6), Pergamon Press, Oxford, 1995; Elsevier Science, 2006; (b) R. Peters, Z.-Q. Xin, D.F. Fischer, W.B. Schweizer, Organometallics 25 (2006) 2917;

(c) M. El-khateeb, H. Görls, W. Weigand, J. Organomet. Chem. 691 (2006) 5816.

[2] J.L. Hubbard, W.K. McVicar, Organometallics 9 (1990) 2683.

[3] (a) Y.-P. Wang, T.-S. Lin, Y.-H. Yang, J.-H. Liaw, S.-L. Wang, F.-L. Liao, Y.-J. Lu, J. Organomet. Chem. 503 (1995) 35;

(b) Y.-P. Wang, X.-H. Lui, B.-S. Lin, W.-D. Tang, T.-S. Lin, J.-H. Liaw, Y. Wang, Y.-H. Liu, J. Organomet. Chem. 575 (1999) 310.

[4] E.W. Slocum, C.R. Ernst, Adv. Organomet. Chem. 10 (1972) 79.

[5] We have reported cases of $\mathrm{CpCr}(\mathrm{NO})_{2} \mathrm{Cl}, \mathrm{CpCr}(\mathrm{NO})_{2} \mathrm{I}$, and $\mathrm{CpCr}(\mathrm{NO})_{2}\left(\mathrm{CH}_{3}\right)$ in Y.-P. Wang, Y.-H. Yang, S.-L. Wang, F.-L. Liao, J. Organomet. Chem. 419 (1991) 325.

[6] T.S. Piper, G. Wilkinson, J. Inorg. Nucl. Chem. 2 (1956) 38.

[7] M.A. Jennings, A. Wojcicki, J. Organomet. Chem. 14 (1968) 231.

[8] M.D. Rausch, E.A. Mintz, D.W. Macomber, J. Org. Chem. 45 (1980) 689.

[9] Y.-P. Wang, J.-M. Hwu, J. Organomet. Chem. 399 (1990) 141.

[10] T.E. Sloan, A. Wojcicki, Inorg. Chem. 7 (1968) 1268.
[11] P.K. Atanassov, Y. Zhou, A. Linden, H. Heimgartner, Helv. Chim. Acta 85 (2002) 1102.

[12] M. Minozzi, D. Nanni, J.C. Walton, J. Org. Chem. 69 (2004) 2056.

[13] J.B. Stotter (Ed.), Carbon-13 NMR Spectroscopy, Academic Press, New York, 1972.

[14] B.E. Mann, Adv. Organomet. Chem. 12 (1974) 135.

[15] A.A. Koridze, P.V. Petrovskii, A.I. Mokhov, A.I. Lutsenko, J. Organomet. Chem. 136 (1977) 57.

[16] D.W. Macomber, M.D. Rausch, Organometallics 2 (1983) 1523.

[17] International Tables for X-ray Crystallography, vol. IV. Kynoch, Birmingham, UK, 1974.

[18] E.J. Gabe, Y. LePage, J.-P. Charland, F.L. Lee, P.S. White, J. Appl. Crystallogr. 22 (1989) 384.

[19] R.D. Rogers, R. Shakir, J.L. Atwood, D.W. Macomber, Y.-P. Wang, M.D. Rausch, J. Crystallogr. Spectrosc. Res 18 (1988) 767.

[20] M.A. Bush, G.A. Sim, J. Chem. Soc. (A) (1970) 605.

[21] A.D. Becke, J. Chem. Phys. 98 (1993) 5648.

[22] C. Lee, W. Yang, R.G. Parr, Phys. Rev. B 37 (1988) 785.

[23] M.J. Frisch, G.W. Trucks, H.B. Schlegel, G.E. Scuseria, M.A. Robb, J.R. Cheeseman, J.A. Montgomery Jr., T. Vreven, K.N. Kudin, J.C. Burant, J.M. Millam, S.S. Iyengar, J. Tomasi, V. Barone, B. Mennucci, M. Cossi, G. Scalmani, N. Rega, G.A. Petersson, H. Nakatsuji, M. Hada, M. Ehara, K. Toyota, R. Fukuda, J. Hasegawa, M. Ishida, T. Nakajima, Y. Honda, O. Kitao, H. Nakai, M. Klene, X. Li, J.E. Knox, H.P. Hratchian, J.B. Cross, C. Adamo, J. Jaramillo, R. Gomperts, R.E. Stratmann, O. Yazyev, A.J. Austin, R. Cammi, C. Pomelli, J.W. Ochterski, P.Y. Ayala, K. Morokuma, G.A. Voth, P. Salvador, J.J. Dannenberg, V.G. Zakrzewski, S. Dapprich, A.D. Daniels, M.C. Strain, O. Farkas, D.K. Malick, A.D. Rabuck, K. Raghavachari, J.B. Foresman, J.V. Ortiz, Q. Cui, A.G. Baboul, S. Clifford, J. Cioslowski, B.B. Stefanov, G. Liu, A. Liashenko, P. Piskorz, I. Komaromi, R.L. Martin, D.J. Fox, T. Keith, M.A. Al-Laham, C.Y. Peng, A. Nanayakkara, M. Challacombe, P.M.W. Gill, B. Johnson, W. Chen, M.W. Wong, C. Gonzalez, J.A. Pople, Gaussian 03, Revision C.02, Gaussian, Inc., Wallingford, CT, 2004.

[24] A.E. Reed, L.A. Curtiss, F. Weinhold, Chem. Rev. 88 (6) (1988) 899. 